Article

\title{
Poly(Acrylic acid)-Based Hybrid Inorganic-Organic Electrolytes Membrane for Electrical Double Layer Capacitors Application
}

\author{
Chiam-Wen Liew ${ }^{1,2}$, H.M. Ng ${ }^{1}$, Arshid Numan ${ }^{1}$ and S. Ramesh ${ }^{1, *}$ \\ 1 Centre for Ionics University of Malaya, Department of Physics, Faculty of Science, University of Malaya, \\ LembahPantai, 50603 Kuala Lumpur, Malaysia; liewchiamwen85@gmail.com (C.-W.L.); \\ nghonming@hotmail.com (H.M.N.); numan.arshed@yahoo.com (A.N.) \\ 2 School of Foundation Studies, Xiamen University Malaysia Campus, Jalan Suria Serenia 1, Bandar Serenia, \\ 43900 Sepang, Malaysia \\ * Correspondence: rameshtsubra@gmail.com; Tel.: +60-3-7967-4391; Fax: +60-3-7967-4146
}

Academic Editor: Hsing-Lin Wang

Received: 12 March 2016; Accepted: 26 April 2016; Published: 18 May 2016

\begin{abstract}
Nanocomposite polymer electrolyte membranes (NCPEMs) based on poly(acrylic acid)(PAA) and titania $\left(\mathrm{TiO}_{2}\right)$ are prepared by a solution casting technique. The ionic conductivity of NCPEMs increases with the weight ratio of $\mathrm{TiO}_{2}$. The highest ionic conductivity of $(8.36 \pm 0.01) \times 10^{-4} \mathrm{~S} \cdot \mathrm{cm}^{-1}$ is obtained with addition of $6 \mathrm{wt} \%$ of $\mathrm{TiO}_{2}$ at ambient temperature. The complexation between PAA, LiTFSI and $\mathrm{TiO}_{2}$ is discussed in Attenuated total reflectance-Fourier Transform Infrared (ATR-FTIR) studies. Electrical double layer capacitors (EDLCs) are fabricated using the filler-free polymer electrolyte or the most conducting NCPEM and carbon-based electrodes. The electrochemical performances of fabricated EDLCs are studied through cyclic voltammetry (CV) and galvanostatic charge-discharge studies. EDLC comprising NCPEM shows the specific capacitance of $28.56 \mathrm{~F} \cdot \mathrm{g}^{-1}$ (or equivalent to $29.54 \mathrm{mF} \cdot \mathrm{cm}^{-2}$ ) with excellent electrochemical stability.
\end{abstract}

Keywords: poly(acrylic acid); $\mathrm{TiO}_{2}$; nanocomposite polymer electrolyte membrane; EDLCs; capacitance

\section{Introduction}

Solid polymer electrolyte (SPE) membranes are good candidates to replace conventional liquid electrolytes because of their attractive properties, such as ease of handling and manufacturing, the fact they can be configured in any shape due to their flexible polymer matrix, their wide operating temperature range, low volatility, high energy density, no new technology requirements, low electronic conductivity and negligible vapor pressure [1-4]. Other features are excellent electrochemical, structural, thermal, photochemical and chemical stabilities, lightness in weight and better safety performance, as SPEs can eliminate the problems of corrosive solvent leakage and harmful gas during operation [5-7]. However, the ionic conductivity of SPEs is extremely low. Therefore, several approaches have been taken to improve the ionic conductivity of polymer electrolytes; for example, addition of additives like plasticizers, ionic liquids, fillers and/or liquid crystals, blending of two different polymers, modifications on the polymers and irradiation with gamma $(\gamma)$ rays as well as mix salt systems.

Among all the approaches, doping of fillers is an alternative way to enhance the ionic conductivity of SPEs. Apart from ionic conductivity, addition of fillers increases the mechanical integrity of polymer electrolyte membranes. Addition of fillers can improve interfacial stability between electrodes and electrolytes, enhance cationic diffusivity by altering the ionic transport properties, reduce the water 
retention of polymer electrolyte membranes and decrease glass transition temperature $\left(T_{\mathrm{g}}\right)$ of the polymer matrix [8-13]. Nanotechnology has received an upsurge of interest in recent years. Nano-sized fillers have become popular materials to substitute the larger particle size of fillers due to their high surface area. Nano-scaled fillers provide high activity, exhibit good chemical stability and form rapidly in the space charge region between the grains in comparison to micro-sized fillers $[8,14,15]$. PAA is a non-toxic, hydrophilic and biocompatible superabsorbent polymer with a three dimensional (3-D) network [16-18]. PAA was chosen as a host polymer in this research due to its fascinating behaviors such as excellent stability in acidic and basic media, high ionic conductivity, strong adhesive properties, superior selectivity and permeability and high ability to associate with a variety of multivalent metal ions in solution [18-21]. PAA can suppress the crystallization and form stable complexes with metal $[18,22,23]$. The main reason for choosing PAA as a host polymer is because of its high charge density based on carboxylic $(-\mathrm{COOH})$ functional group. This functional group favors the bond formation-for example, ionic, covalent, hydrogen and coordination-which can be used to form complexation with the nanoparticles $[24,25]$. The ionization of the carboxylic group in PAA depends mainly on $\mathrm{pH}$ and ionic strength $[26,27]$. The charge density of PAA is low in acidic media due to the poor degree of dissociation. The ions can just be dissociated well in the solution at higher $\mathrm{pH}$ values $(\mathrm{pH}>5)$.

Lithium bis(trifluoromethane)sulfonimide (LiTFSI) was selected because of its non-corrosive behavior towards electrodes, wide electrochemical stability, excellent thermal stability and superior thermal properties. Apart from that, this salt can dissociate very well even in low dielectric solvents. It is a newly designed metal salt to replace the poor conducting lithium triflate (LiTf), the hazardous lithium perchlorate $\left(\mathrm{LiClO}_{4}\right)$, the thermally unstable $\mathrm{LiBF}_{4}$ and lithium hexafluorophosphate $\left(\mathrm{LiPF}_{6}\right)$, and the toxic lithium hexafluoroarsenate $\left(\mathrm{LiAsF}_{6}\right)$ [28]. The extensive delocalized electrons in TFSI $^{-}$anion can promote the ion dissociation and thereby increase the ionic conductivity [29]. The attempt of using $\mathrm{TiO}_{2}$ is due to its numerous outstanding features, such as improved physical and electrochemical stabilities, enhanced cationic transport number, hydrophilic, good mechanical integrity, improved sinterability and excellent stability in acidic and oxidative environments with free-flowing structure [14,30-32]. Other properties are excellent mechanical and thermal resistances, hydrophilic nature and high ionic exchange capacity (IEC) $[10,33]$. There are many applications for $\mathrm{TiO}_{2}$ such as beam splitters, optical and anti-reflection coatings, heterogeneous catalysis, gas sensors, ultraviolet (UV) absorbers, lithium batteries, optical, electronic and electrochromic devices, self-cleaning surface coatings, UV-resistant coatings and paints, solar cells, disinfectant sprays, water treatment agents and topical sunscreens. Nano-sized $\mathrm{TiO}_{2}$ is also used in clean technologies such as environmental remediation, pigments, paints, ceramics, cosmetics and solar energy conversion due to its high photocatalytic activity and chemical stability $[30,31,34,35]$. Ning and coworkers prepared Mn-doped $\mathrm{TiO}_{2}$ micro/nanostructure porous film through an anodization of Ti-Mn alloy. The film annealed at $300{ }^{\circ} \mathrm{C}$ produces the highest capacitance of $1451.3 \mathrm{mF} / \mathrm{cm}^{2}$ at a current density of $3 \mathrm{~mA} / \mathrm{cm}^{2}$. This film can be used as a high-performance supercapacitor electrode [36]. $\mathrm{TiO}_{2}$ can also be used to improve photocatalytic degradation of methylene blue by preparing reduced graphene-oxide/titanium dioxide/zinc oxide ternary nanocomposites as proven by Raghavan et al. [37]. To date, EDLC based on PAA-LiTFSI- $\mathrm{TiO}_{2}$ polymer electrolyte membranes have never been reported in literature. Therefore, the main aim of this research work is to investigate the effect of $\mathrm{TiO}_{2}$ nanoparticles on PAA-LiTFSI polymer matrix and EDLC application.

\section{Experimental Section}

\subsection{Materials}

The NCPEMs comprising PAA, LiTFSI and $\mathrm{TiO}_{2}$ were prepared by a solution casting method. PAA (from Sigma-Aldrich, St. Louis, MI, USA, molecular weight of 3,000,000 g. $\mathrm{mol}^{-1}$ ), LiTFSI (from Sigma-Aldrich) and $\mathrm{TiO}_{2}$ (from Sigma-Aldrich with particle size of $<100 \mathrm{~nm}$ ) are used as host polymer, 
doping salt and fillers, respectively. All the materials were obtained from Sigma-Aldrich. All the materials were used as received.

\subsection{Preparation of Filler Added Poly(Vinyl Alcohol)-Based Polymer Electrolyte Membranes}

PAA-LiTFSI solution was initially dissolved in deionized water. After that, an appropriate amount of $\mathrm{TiO}_{2}$ was added into the solution. The resulting solution was subjected to sonicator for $1 \mathrm{~h}$ at $70^{\circ} \mathrm{C}$ and stirred overnight at $50{ }^{\circ} \mathrm{C}$. The solution was then cast on Petri dish and thus dried in an oven at $50{ }^{\circ} \mathrm{C}$. Polymer electrolyte membranes were eventually formed. The sample designation and the weight ratio of each material used in the research are tabulated in Table 1.

Table 1. The composition of each material used in the polymer electrolyte membrane preparation, the designation of the polymer electrolyte membranes and the ionic conductivity of the polymer electrolyte membranes.

\begin{tabular}{|c|c|c|c|c|}
\hline \multirow{2}{*}{$\begin{array}{c}\text { Sample } \\
\text { designation }\end{array}$} & \multicolumn{3}{|c|}{ Weight percent of material (wt \%) } & \multirow[t]{2}{*}{ Ionic conductivity $\left(\mathrm{S} \cdot \mathrm{cm}^{-1}\right)$} \\
\hline & PAA & LiTFSI & $\mathrm{TiO}_{2}$ & \\
\hline Ti 0 & 70 & 30 & 0 & $(1.04 \pm 0.01) \times 10^{-6}$ \\
\hline Ti 1 & 68.6 & 29.4 & 2 & $(2.88 \pm 0.02) \times 10^{-4}$ \\
\hline Ti 2 & 67.2 & 28.8 & 4 & $(4.04 \pm 0.01) \times 10^{-4}$ \\
\hline Ti 3 & 65.8 & 28.2 & 6 & $(8.36 \pm 0.01) \times 10^{-4}$ \\
\hline $\mathrm{Ti} 4$ & 64.4 & 27.6 & 8 & $(4.65 \pm 0.01) \times 10^{-4}$ \\
\hline Ti 5 & 63 & 27 & 10 & $(3.22 \pm 0.01) \times 10^{-4}$ \\
\hline
\end{tabular}

\subsection{Characterization of Polymer Electrolyte Membranes}

\subsubsection{Ionic Conductivity Studies}

Ionic conductivity of polymer electrolyte membranes was studied by HIOKI 3532-50 LCR HiTESTER impedance analyzer (HIOKI, Nagano, Japan) over a frequency range between $50 \mathrm{~Hz}$ and $5 \mathrm{MHz}$ at a signal level of $10 \mathrm{mV}$. The measurement was taken in the configuration of stainless steel (SS) blocking electrode/polymer electrolyte/SS electrode at ambient temperatures.

\subsubsection{Attenuated Total Reflectance-Fourier Transform Infrared (ATR-FTIR)}

ATR-FTIR analysis was performed by Themoscientific Nicolet iS10 FTIR Spectrometer (Thermo Fisher Scientific, Waltham, MA, USA). This spectrometer is equipped with an ATR internal reflection system. The FTIR spectra were recorded with a resolution of $1 \mathrm{~cm}^{-1}$ in transmittance mode over the wavenumber range from 4000 and $650 \mathrm{~cm}^{-1}$. The FTIR spectra and peak deconvolution were scrutinized using OMNIC 8 software which is provided by Thermo Fischer Scientific Inc. The transmittance mode of FTIR spectra was initially converted into absorbance mode for peak deconvolution process. In order to deconvolute the FTIR spectra, baseline correction and curve fitting must be implemented. The FTIR curve was fitted with Gaussian-lorentzian mixed mode.

\subsubsection{Morphological Studies}

The surface morphology of the polymer electrolytes was studied using field emission scanning electron microscope (FESEM; JEOL JSM-7600F, Akishima, Tokyo, Japan). The polymer electrolytes was coated with platinum coating to prevent charging. The images were taken at an accelerating voltage of $5 \mathrm{kV}$.

\subsubsection{Linear Sweep Voltammetry (LSV)}

CHI600D electrochemical analyzer was used to evaluate LSV responses of filler-free polymer electrolyte and the most conducting filler-added polymer electrolyte. These cells were analyzed at a 
scan rate of $10 \mathrm{mV} \cdot \mathrm{s}^{-1}$ by placing the polymer electrolyte between $\mathrm{SS}$ electrodes in the potential range of $\pm 3 \mathrm{~V}$.

\subsection{Electrode Preparation}

Activated carbon-based EDLC electrodes were prepared by a dip coating technique. The preparation of carbon slurry was prepared by mixing $80 \mathrm{wt} \%$ activated carbon (Kuraray Chemical Co Ltd., Osaka City, Japan) of particle size between 5 and $20 \mu \mathrm{m}$, surface area between 1800 and $2000 \mathrm{~m}^{2} \cdot \mathrm{g}^{-1}, 5 \mathrm{wt} \%$ carbon black (Super P), $5 \mathrm{wt} \%$ multi-walled carbon nanotubes (CNTs) (Sigma-Aldrich) with outer diameter, O.D. between 7 and $15 \mathrm{~nm}$ and length, $L$ ranging from 0.5 to $10 \mu \mathrm{m}$ ) and $10 \mathrm{wt} \%$ poly(vinylidene fluoride) (PVDF) binder (molecular weight of 534,000 $\mathrm{g} \cdot \mathrm{mol}^{-1}$ from Aldrich) and dissolving them in 1-methyl-2-pyrrolidone(Purity $\geqslant 99.5 \%$ from Merck, Darmstadt, Germany). Activated carbon was initially treated with sodium hydroxide $(\mathrm{NaOH})$ and sulfuric acid $\left(\mathrm{H}_{2} \mathrm{SO}_{4}\right)$ to increase the porosity of carbon. This slurry was stirred thoroughly for several hours at ambient temperature. The carbon slurry was then dip coated on an aluminum mesh current collector. The coated electrodes were dried in an oven at $110^{\circ} \mathrm{C}$.

\subsection{EDLC Fabrication}

EDLC cell was constructed in the configuration of electrode/polymer electrolyte/electrode. The EDLC cell configuration was eventually placed in a cell kit for further electrochemical analyses.

\subsection{EDLC Characterization}

The fabricated EDLC cell was subsequently subjected to cyclic voltammetry (CV) and galvanostatic charge-discharge (GCD) for characterization.

\subsubsection{Cyclic Voltammetry (CV)}

The CV study of EDLC was investigated using CHI600D electrochemical analyzer $(\mathrm{CH}$ Instruments, Austin, TA, USA). The cell was rested for $2 \mathrm{~s}$ prior to the measurement. The EDLC cell was then evaluated at $10 \mathrm{mV} \cdot \mathrm{s}^{-1}$ scan rate in the potential range between 0 and $1 \mathrm{~V}$ in intervals of $0.001 \mathrm{~V}$. The specific capacitance $\left(C_{\mathrm{sp}}\right)$ of EDLC was computed using the following equations:

$$
\begin{gathered}
C_{\mathrm{sp}}=\frac{i}{s m}\left(\mathrm{~F} \cdot \mathrm{g}^{-1}\right) \\
C_{\mathrm{sp}}=\frac{i}{s A}\left(\mathrm{~F} \cdot \mathrm{cm}^{-2}\right)
\end{gathered}
$$

where $i$ is the average anodic-cathodic current (A), $s$ is the potential scan rate $\left(\mathrm{V} \cdot \mathrm{s}^{-1}\right), m$ refers to the average mass of active materials and $A$ represents surface area of the electrodes. The average mass of electrode materials is around $0.01 \mathrm{~g}$, whereas the surface area of the electrode is $1 \mathrm{~cm}^{-2}$.

\subsubsection{Galvanostatic Charge-Discharge Performance (GCD)}

The charge-discharge study was carried out using a Neware battery cycler. EDLC was charged and discharged at a current of $1 \mathrm{~mA}$ and current density of $1 \mathrm{~mA} \cdot \mathrm{cm}^{-2}$. EDLC was allowed to rest for $10 \mathrm{~min}$ before taking the measurements. The specific discharge capacitance $\left(C_{\mathrm{sp}}\right)$ was obtained from charge-discharge curves, according to the following relationship:

$$
C_{\mathrm{sp}}=\frac{I}{m\left(\frac{\mathrm{d} V}{\mathrm{~d} t}\right)}
$$

where $I$ is the applied current (A), $m$ is the average mass of electrode materials, $\mathrm{d} V$ represents the potential change of a discharging process excluding the internal resistance drop occurring at the 
beginning of the cell discharge and $\mathrm{d} t$ is the time interval of discharging process. The $\mathrm{d} V / \mathrm{d} t$ is determined from the slope of the discharge curve.

Energy density, $E\left(\mathrm{~W} \cdot \mathrm{h} \cdot \mathrm{kg}^{-1}\right)$, power density, $P\left(\mathrm{~kW} \cdot \mathrm{kg}^{-1}\right)$ and Coulombic efficiency, $\eta(\%)$ were assessed using the equations below

$$
\begin{gathered}
E=\frac{C_{\mathrm{sp}} \times(\mathrm{d} V)^{2}}{2} \times \frac{1000}{3600} \\
P=\frac{I \times \mathrm{d} V}{2 \times m} \times 1000 \\
\eta=\frac{t_{\mathrm{d}}}{t_{\mathrm{c}}} \times 100 \%
\end{gathered}
$$

where $t_{\mathrm{d}}$ and $t_{\mathrm{c}}$ are the discharging and charging times, respectively.

\section{Results}

\subsection{Ambient Temperature-Ionic Conductivity Studies}

Table 1 illustrates the ionic conductivity of polymer electrolyte membranes versus the weight percentage of $\mathrm{TiO}_{2}$.

\subsection{Attenuated Total Reflectance-Fourier Transform Infrared (ATR-FTIR)}

Figure 1 depicts the ATR-FTIR spectrum of PAA, LiTFSI, Ti 0 and Ti 3.

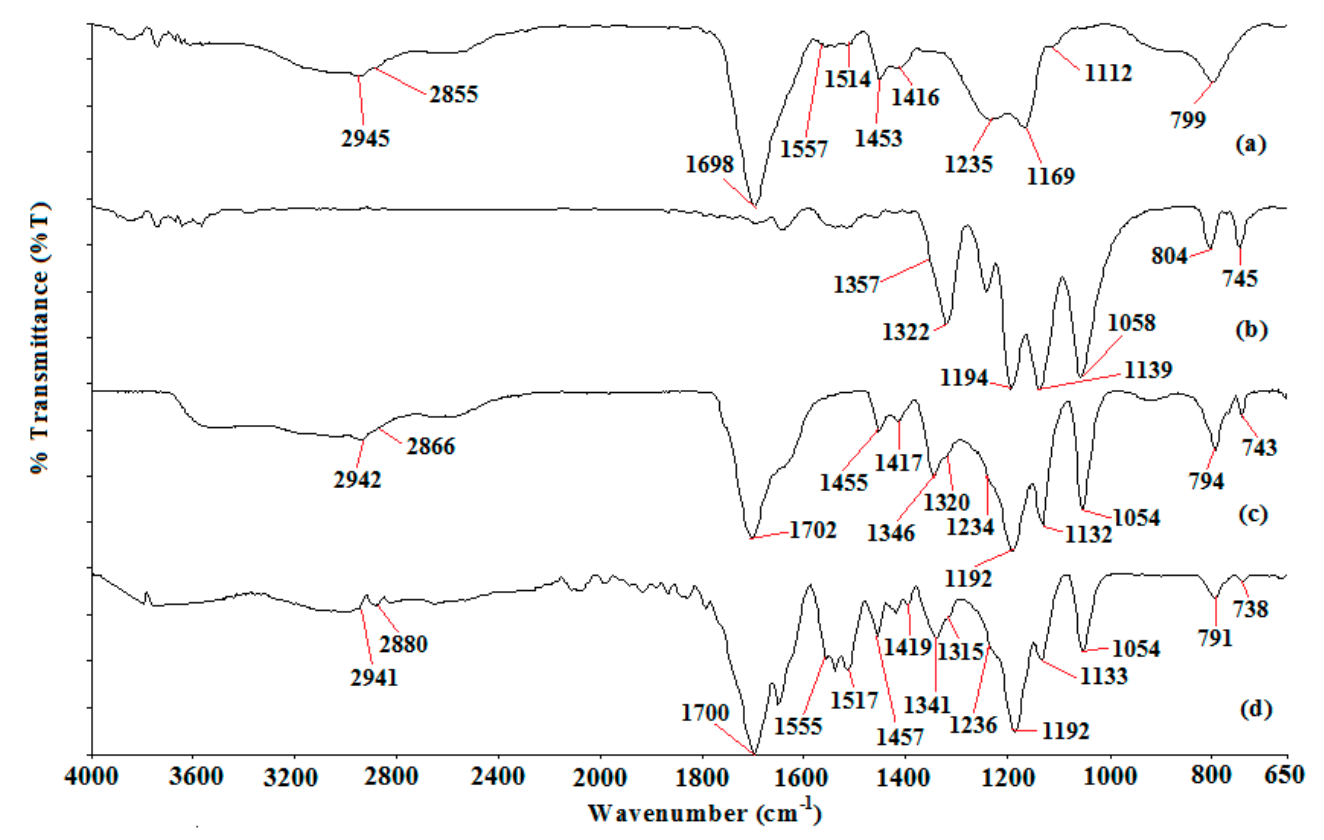

Figure 1. FTIR spectrum of (a) PAA; (b) LiTFSI; (c) Ti 0 and (d) Ti 3.

\subsection{Morphological Studies}

Figure $2 \mathrm{a}$, $\mathrm{b}$ shows the scanning electron micrograph of filler-free polymer electrolyte (Ti 0 ) and the highest conducting nanocomposite polymer electrolyte (Ti 3). 


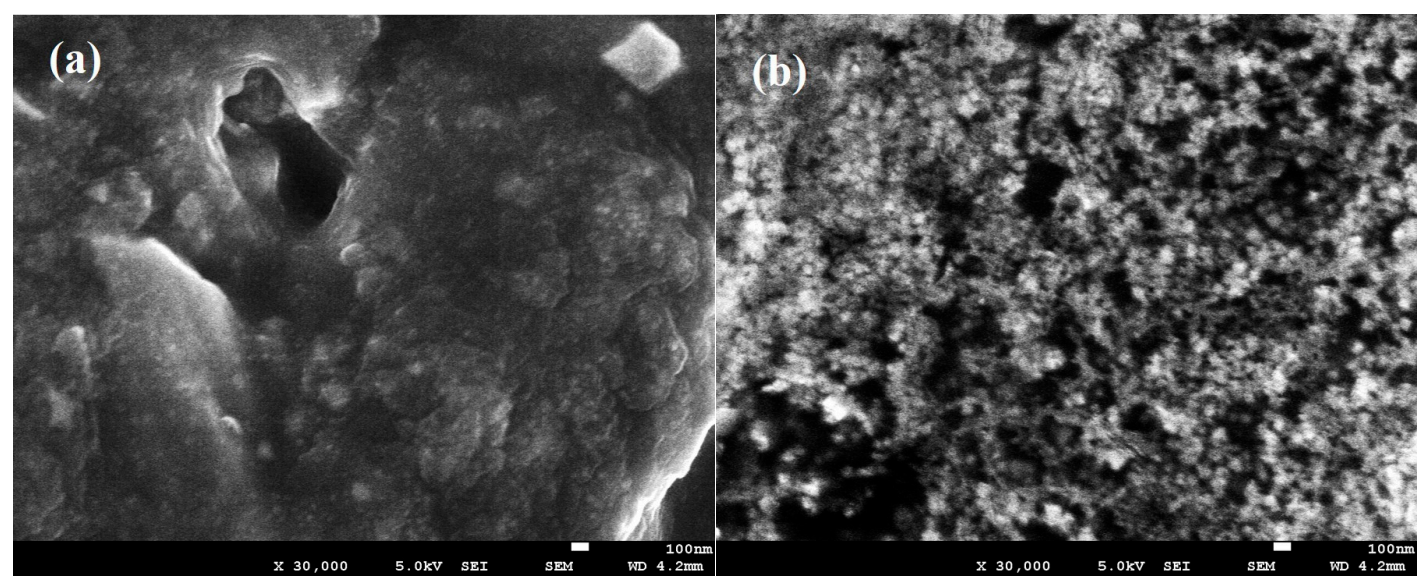

Figure 2. SEM images of (a) Ti 0 and (b) Ti 3.

\subsection{Linear Sweep Voltammetry (LSV)}

Figure $3 \mathrm{a}, \mathrm{b}$ portray the electrochemical potential window of filler-free polymer electrolyte and the highest conducting nanocomposite polymer electrolyte.

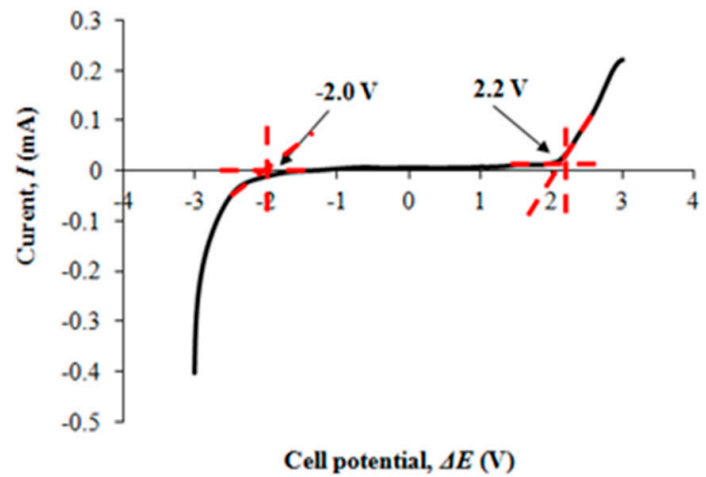

(a)

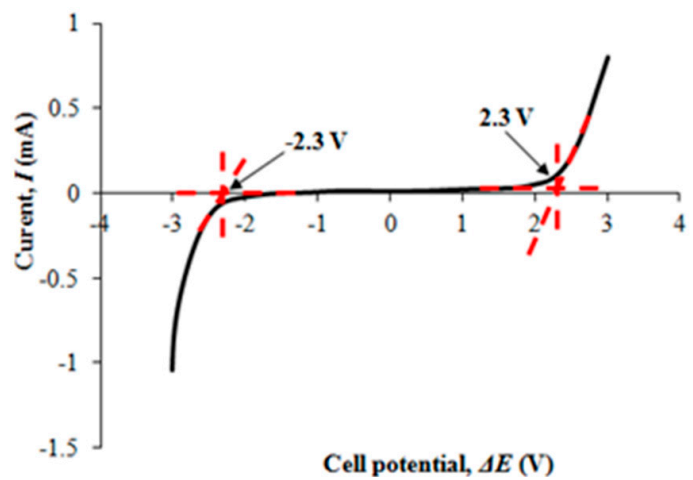

(b)

Figure 3. (a) LSV response tp filler-free polymer electrolyte; (b) LSV response to Ti 3.

\subsection{Cyclic Voltammetry (CV)}

Figure $4 \mathrm{a}, \mathrm{b}$ depict the cyclic voltammetry of EDLC comprising of filler free polymer electrolyte and the highest conducting nanocomposite polymer electrolyte.

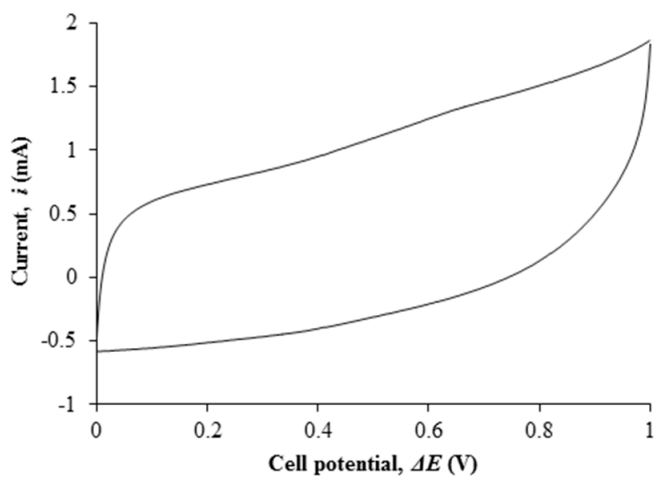

(a)

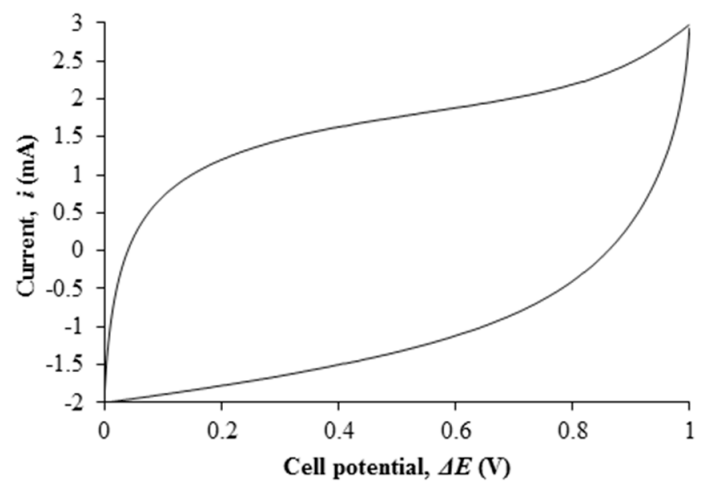

(b)

Figure 4. (a) Cyclic voltammetry of Ti 0-based EDLC; (b) Cyclic voltammetry of Ti 3-based EDLC. 


\subsection{Galvanostatic Charge-Discharge Performance (GCD)}

Figure 5 illustrates the GCD performance of EDLC containing the highest conducting polymer electrolyte over first five cycles of charging and discharging.

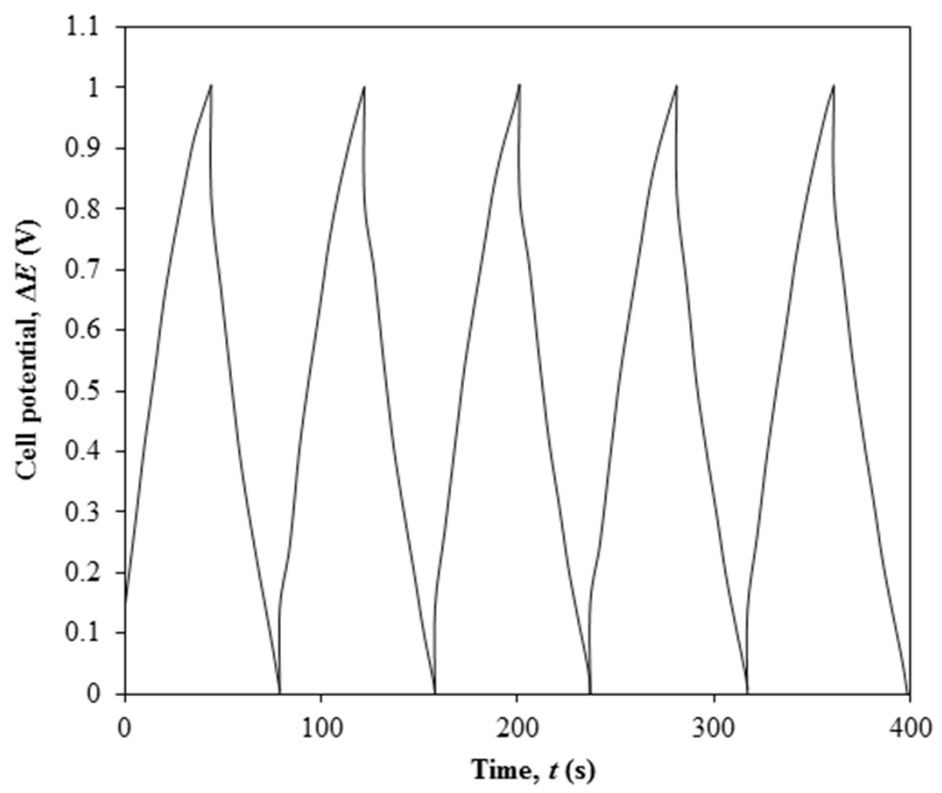

Figure 5. Galvanostatic charge-discharge result of Ti 3-based EDLC upon 5 cycles of charging and discharging.

The findings on the electrochemical stability of the EDLC are illustrated in Figures 6 and 7. Figure 6 exemplifies specific capacitance and Coulombic efficiency of the EDLC over 3000 cycles of charging and discharging.

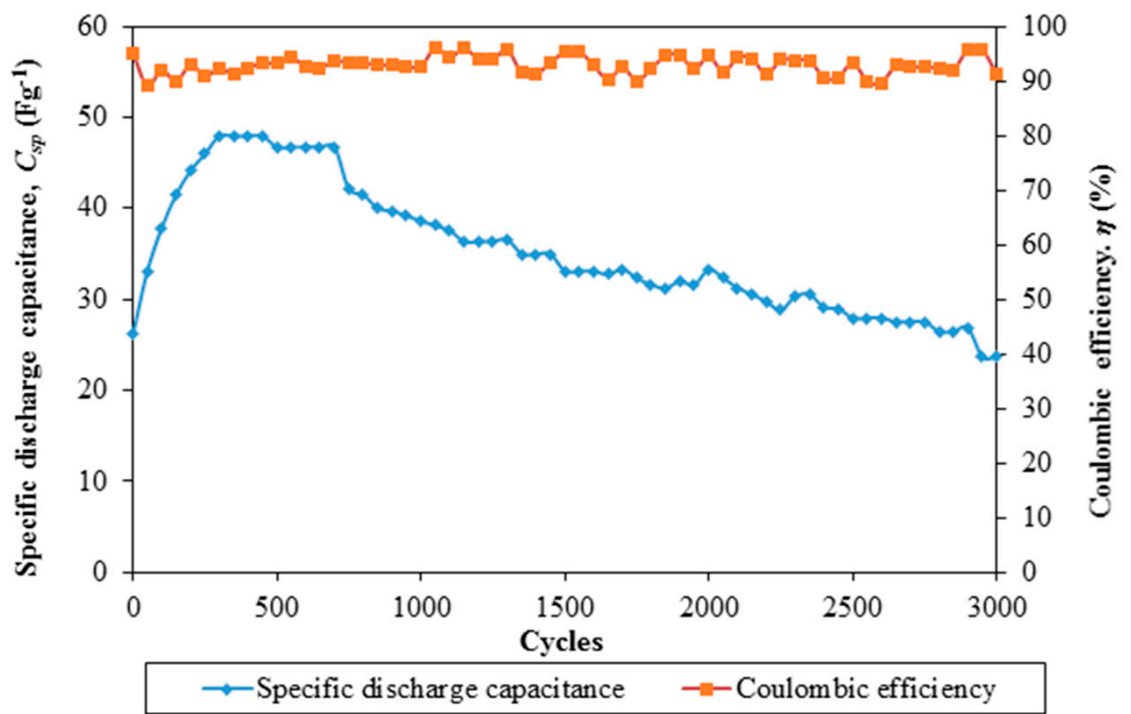

Figure 6. Specific discharge capacitance and Coulombic efficiency of Ti 3-based EDLC over 3000 cycles of charging and discharging. 


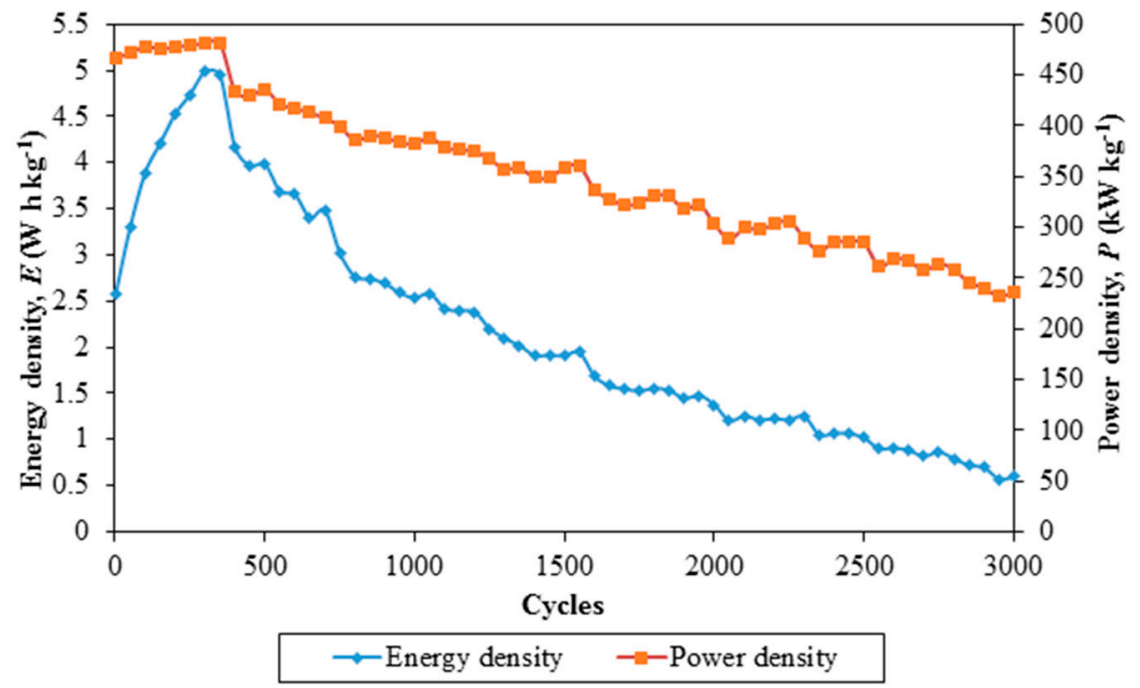

Figure 7. Energy density and power density of Ti 3-based EDLC over 3000 cycles of charging and discharging.

In contrast, Figure 7 demonstrates energy density and power density of the EDLC over 3000 cycles of charging and discharging.

\section{Discussion}

\subsection{Ambient Temperature-Ionic Conductivity Studies}

The ionic conductivity of polymer electrolyte membranes is increased by two orders of magnitude from $(1.04 \pm 0.01) \times 10^{-6}$ to $(8.36 \pm 0.01) \times 10^{-4} \mathrm{~S} \cdot \mathrm{cm}^{-1}$ upon addition of $6 \mathrm{wt} \%$ of $\mathrm{TiO}_{2}$. Filler plays an important role as a solid plasticizer. The filler absorbs and retains the electrolyte solution in the polymer network. As a result, this retention raises the mobility of charge carriers which are transported from one site to another vacant site. The increase in ionic conductivity of nanocomposite polymer electrolyte membranes is also due to the formation of 3-D networks. Native hydroxyl groups will be formed on the surface of the filler particles when the fillers are dispersed in water. These 3-D networks can provide a new pathway (a space charge layer) for an ion conduction mechanism when the nanoparticles get closer to each other. Therefore, the ionic conductivity of nanocomposite polymer electrolyte membranes is higher than filler-free polymer electrolyte. Addition of fillers reduces the degree of crystallinity of polymer electrolyte membranes and favors the ion hopping process in the amorphous region of the polymer matrix.

We postulate an idea for the ion conduction mechanism in the polymer electrolyte membranes as shown in Figure 8.

We suggest that the hydrogen from the carboxylic group in PAA is initially deprotonated. As a result, carboxylate anions are produced in PAA chains after the deprotonation. Lithium cations are thus dissociated from TFSI anions due to their low lattice energy and low tendency to form ion pairs [38]. Then, the mobile lithium cations (also known as charge carriers) form the partial bond with the carboxylate anions. After that, the charge carriers are transported to another vacant site after the partial bonding between oxygen and lithium is broken down. The ionic conductivity of polymer electrolyte membranes is generated with the repeating ion transportation within the membrane. The ionic conductivity of nanocomposite polymer electrolyte is decreased gradually above addition of $6 \mathrm{wt} \%$ of $\mathrm{TiO}_{2}$. The reduction of ionic conductivity is primarily attributed to excess nano-sized particles. The aggregation of these particles would block the conducting path and impede the ion conduction in the electrolyte. 

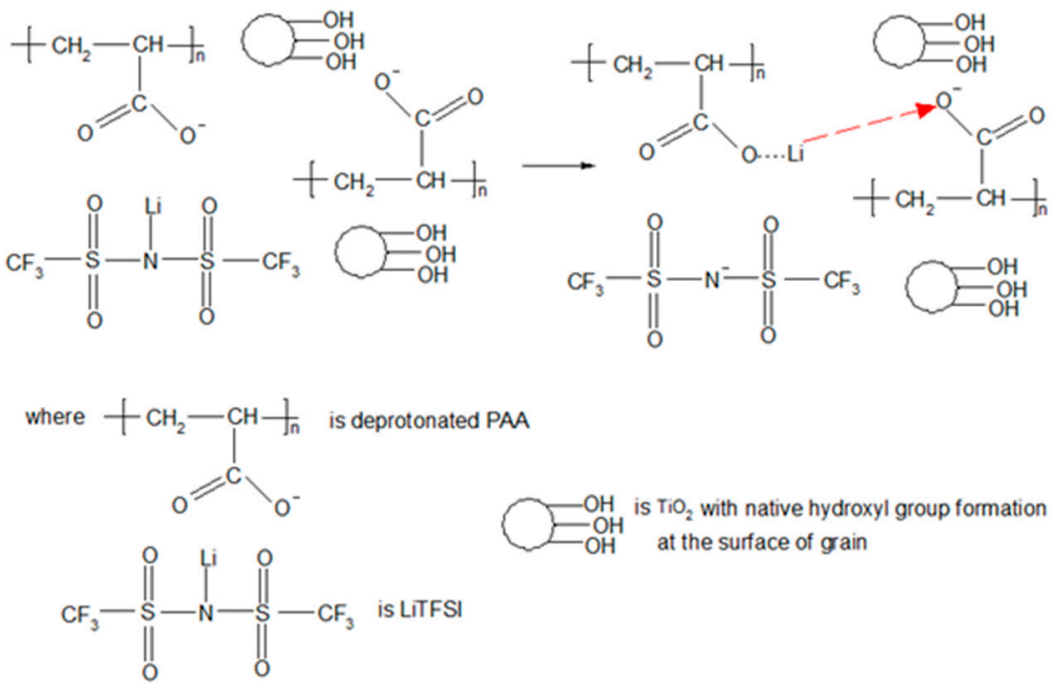

Figure 8. The proposed ion conduction mechanism in nanocomposite polymer electrolyte membranes.

\subsection{Attenuated Total Reflectance-Fourier Transform Infrared (ATR-FTIR)}

The assignment of all possible peaks is listed in Table 2.

Table 2. Peak assignments of PAA, LiTFSI, Ti 0 and Ti 3.

\begin{tabular}{|c|c|c|c|c|c|}
\hline \multirow{2}{*}{ Peak/band assignments } & \multicolumn{4}{|c|}{ Wavenumber $\left(\mathrm{cm}^{-1}\right)$} & \multirow{2}{*}{ References } \\
\hline & PAA & LiTFSI & Ti 0 & Ti 3 & \\
\hline S-N stretching mode of LiTFSI & - & 745 & 743 & 738 & [39] \\
\hline $\begin{array}{l}\text { Combination of C-S stretching and S-N } \\
\text { asymmetric stretching mode of LiTFSI }\end{array}$ & - & 804 & 794 & 791 & [39] \\
\hline $\mathrm{CH}_{2}$ rocking mode of $\mathrm{PAA}$ & 799 & - & 794 & 791 & [40] \\
\hline S-N-S asymmetric stretching mode of LiTFSI & - & 1,058 & 1,054 & 1,054 & [39] \\
\hline $\mathrm{C}-\mathrm{CH}_{2}$ stretching mode of PAA & 1,112 & - & - & - & [24] \\
\hline $\begin{array}{l}\text { Combination of } \mathrm{C}-\mathrm{F} \text { stretching mode and } \\
\mathrm{C}-\mathrm{SO}_{2}-\mathrm{N} \text { bonding mode of LiTFSI }\end{array}$ & - & 1,139 & 1,132 & 1,133 & {$[29,41]$} \\
\hline$-(\mathrm{C}-\mathrm{O}) \mathrm{H}$ stretching mode of PAA & 1,169 & - & - & - & [42] \\
\hline $\mathrm{CF}_{3}$ symmetric stretching mode of LiTFSI & - & 1,194 & 1,192 & 1,192 & [39] \\
\hline $\begin{array}{l}\mathrm{C}-\mathrm{O} \text { stretching coupled with } \mathrm{O}-\mathrm{H} \text { in-plane } \\
\text { bending mode of PAA }\end{array}$ & 1,235 & - & 1,234 & 1,236 & {$[24,40]$} \\
\hline $\mathrm{S}=\mathrm{O}$ asymmetric stretching mode of LiTFSI & - & 1,322 & 1,320 & 1,315 & [41] \\
\hline $\mathrm{SO}_{2}$ asymmetric stretching mode of LiTFSI & - & 1,357 & 1,346 & 1,341 & [39] \\
\hline $\mathrm{CH}_{2}$ bonding mode of PAA & 1,416 & - & 1,417 & 1,419 & [42] \\
\hline$-\mathrm{COO}^{-}$group of PAA & 1,453 & - & 1,455 & 1,457 & [24] \\
\hline $\mathrm{C}=\mathrm{O}$ bending mode of PAA & 1,514 & - & - & 1,517 & [43] \\
\hline$-\mathrm{COO}^{-}$asymmetric stretching mode of PAA & 1,557 & - & - & 1,555 & {$[43,44]$} \\
\hline $\begin{array}{c}\mathrm{C}=\mathrm{O} \text { stretching mode of carboxylic } \\
\text { group in PAA }\end{array}$ & 1,698 & - & 1,702 & 1,700 & {$[18,24,45,46]$} \\
\hline $\mathrm{sp}^{3} \mathrm{C}-\mathrm{H}$ stretching mode of PAA & $\begin{array}{l}2,855 \text { and } \\
2,945\end{array}$ & - & $\begin{array}{l}2,866 \text { and } \\
2,942\end{array}$ & $\begin{array}{c}2,880 \text { and } \\
2,941\end{array}$ & {$[24,39,42,45,46]$} \\
\hline
\end{tabular}

Ti 0 and Ti 3 exhibit all the possible bonding modes of PAA and LiTFSI, except two stretching modes. These two stretching modes are $\mathrm{C}-\mathrm{CH}_{2}$ at a wave number of $1112 \mathrm{~cm}^{-1}$ and $-(\mathrm{C}-\mathrm{O}) \mathrm{H}$ at a 
wave number of $1169 \mathrm{~cm}^{-1}$ from PAA. The disappearance of $-(\mathrm{C}-\mathrm{O}) \mathrm{H}$ stretching mode proves the initial deprotonation of PAA as suggested in the ion conduction mechanism that we proposed in the previous section. LiTFSI spectrum manifests two weak peaks at 745 and $804 \mathrm{~cm}^{-1}$. The first peak is S-N stretching mode, whereas the latter peak is a combination of C-S stretching and S-N asymmetric stretching mode. The first peak exhibits a downward shift to 743 and $738 \mathrm{~cm}^{-1}$. The downward shift reveals the uncoordinated or free TFSI anion [43]. This latter peak becomes more intense (for Ti 0 ) and broader (for Ti 3) upon inclusion of PAA and $\mathrm{TiO}_{2}$. This peak is also shifted to 794 and $791 \mathrm{~cm}^{-1}$ for Ti 0 and Ti 3, respectively. These observations are mainly due to the overlapping with the weak peak at $799 \mathrm{~cm}^{-1}$ which is designated as the $\mathrm{CH}_{2}$ rocking mode of PAA. Broad band is also attained in the high wavenumber region $\left(>2800 \mathrm{~cm}^{-1}\right)$. The $\mathrm{sp}^{3} \mathrm{C}-\mathrm{H}$ stretching mode of PAA shows two broad band regions at 2855 and $2945 \mathrm{~cm}^{-1}$ for PAA, 2866 and $2942 \mathrm{~cm}^{-1}$ for Ti 0 and 2880 and $2941 \mathrm{~cm}^{-1}$ for Ti 3 . The abrupt upward shift for the first band and downward shift for second band indicate the interaction between $\mathrm{C}-\mathrm{H}$ from PAA backbone (where the carboxylate anions are connected) and Li cations.

Two weak peaks 1517 and $1555 \mathrm{~cm}^{-1}$ are obtained in Ti 3 compared with Ti 0 . These peaks originate from $\mathrm{C}=\mathrm{O}$ bending mode of PAA at $1514 \mathrm{~cm}^{-1}$ and $-\mathrm{COO}^{-}$asymmetric stretching mode of PAA at $1557 \mathrm{~cm}^{-1}$ as shown in Figure 1a. The presence of the $-\mathrm{COO}^{-}$asymmetric stretching mode states the deprotonation of the carboxylic acid group in PAA for ion transportation. This is further supported by the peak at $1702 \mathrm{~cm}^{-1}$ for Ti 0 and $1700 \mathrm{~cm}^{-1}$ for Ti 3 . This sharp peak is assigned as $\mathrm{C}=\mathrm{O}$ stretching mode of carboxylic group in PAA. The intensity of this peak is reduced greatly from $31.47 \%$ to $5.44 \%$, in transmittance mode upon dispersion of nano-sized $\mathrm{TiO}_{2}$ as illustrated in Figure 9 .

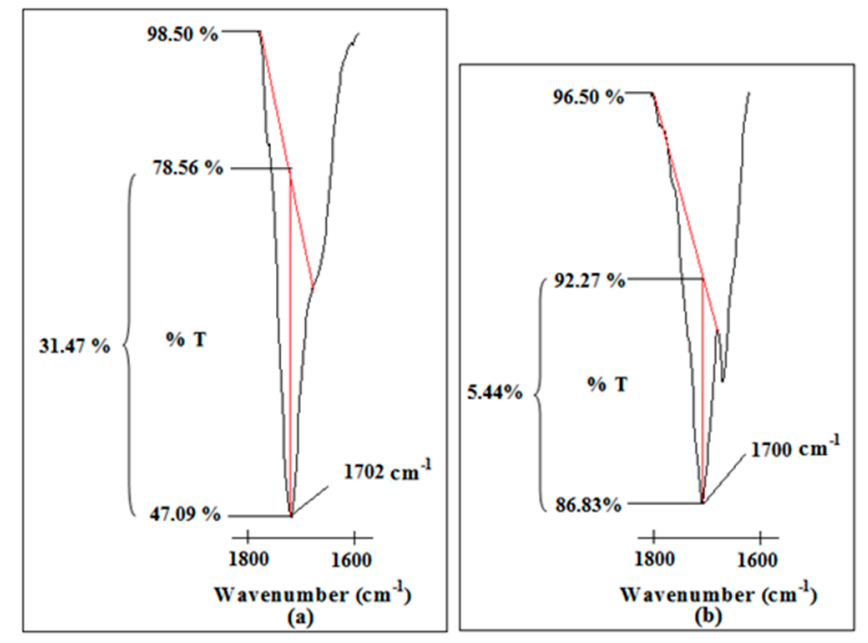

Figure 9. The change in peak intensity of $\mathrm{C}=\mathrm{O}$ stretching mode of carboxylic group of PAA in (a) Ti 0 and (b) Ti 3 .

The reduced peak intensity infers the interaction between the carboxylate anions and lithium cations. A sharp peak, namely the S-N-S asymmetric stretching mode of LiTFSI, is obtained at $1058 \mathrm{~cm}^{-1}$ in the LiTFSI spectrum. This peak undergoes a downward shift to $1058 \mathrm{~cm}^{-1}$ for Ti 0 upon addition of PAA. The peak remains unchanged with inclusion of $\mathrm{TiO}_{2}$. Although the peak remains constant, the peak intensity is reduced from $38.06 \%$ to $4.31 \%$, in transmittance mode. This verifies the effect of adding $\mathrm{TiO}_{2}$ in the polymer complexes.

The bands in the wavenumber region of $1400-1100 \mathrm{~cm}^{-1}$ were explored to further investigate the free ions, ion pairs or ion aggregation [42]. In addition, PAA demonstrates a weak peak at $1453 \mathrm{~cm}^{-1}$ with a shoulder peak at $1416 \mathrm{~cm}^{-1}$. The weak peak is assigned as the $-\mathrm{COO}^{-}$group of PAA, whereas the shoulder peak is related to $\mathrm{CH}_{2}$ bonding mode of PAA. The shape is changed from a weak peak with a shoulder peak to two weak peaks upon addition of LiTFSI and $\mathrm{TiO}_{2}$. The first weak peak is located at $1455 \mathrm{~cm}^{-1}$ for Ti 0 and $1457 \mathrm{~cm}^{-1}$ for Ti 3. On the contrary, another weak peak is placed 
at $1417 \mathrm{~cm}^{-1}$ for Ti 0 and $1419 \mathrm{~cm}^{-1}$ for Ti 3. Apart from the insignificant change in peak location, these peaks exhibit gradual change in peak intensity. The intensity of the weak peak is decreased from $9.63 \%$ to $1.94 \%$ in transmittance mode; meanwhile, the intensity of the shoulder peak is reduced from $3.66 \%$ to $0.67 \%$ in transmittance mode. The ame peak shape is also attained in the wavenumber region of $1400-1300 \mathrm{~cm}^{-1}$. LiTFSI spectrum exemplifies a medium peak at $1322 \mathrm{~cm}^{-1}$ (assigned as $\mathrm{S}=\mathrm{O}$ asymmetric stretching mode of LiTFSI) and a shoulder peak at $1357 \mathrm{~cm}^{-1}$ (attributed to $\mathrm{SO}_{2}$ asymmetric stretching mode of LiTFSI). Addition of $\mathrm{PAA}$ and $\mathrm{TiO}_{2}$ reveals an obvious change in peak shape as shown in Figure 1. The medium peak becomes a shoulder peak, whereas the shoulder peak becomes a weak peak. We notice that the weak peak is located at $1346 \mathrm{~cm}^{-1}$ in transmittance mode for Ti 0 . This peak is shifted downwardly to $1341 \mathrm{~cm}^{-1}$ for Ti 3 . The sign of peak shifting to a lower wavenumber indicates the presence of mobile TFSI anions in Ti 0 and Ti 3 . The lower the wavenumber, the higher is the amount of mobile ions. Therefore, Ti 3 has more free TFSI anions than Ti 0.

LiTFSI spectrum displays two peaks at 1139 and $1194 \mathrm{~cm}^{-1}$ within the range between 1200 and $1100 \mathrm{~cm}^{-1}$. Combination of $\mathrm{C}-\mathrm{F}$ stretching mode and $\mathrm{C}-\mathrm{SO}_{2}-\mathrm{N}$ bonding mode of LiTFSI is the assignment for the first peak. The second peak is appointed as $\mathrm{CF}_{3}$ symmetric stretching mode of LiTFSI. These two peaks are still available in Ti 0 and Ti 3 spectra, but they manifest peak shifting. The first peak is shifted to $1132 \mathrm{~cm}^{-1}$ for Ti 0 and $1133 \mathrm{~cm}^{-1}$ for Ti 3, whereas the latter peak is located at $1192 \mathrm{~cm}^{-1}$ for both samples. An additional shoulder peak is observed in Ti 0 and Ti 3 spectra. We suggest that the presence of the shoulder peak is due to the overlapping with the peak at $1235 \mathrm{~cm}^{-1}$ as proven in Figure 1a. This shoulder peak is designated as $\mathrm{C}-\mathrm{O}$ stretching coupled with $\mathrm{O}-\mathrm{H}$ in-plane bending mode of PAA. We employ a deconvolution technique to confirm the presence of the shoulder peak as illustrated in Figure 10.

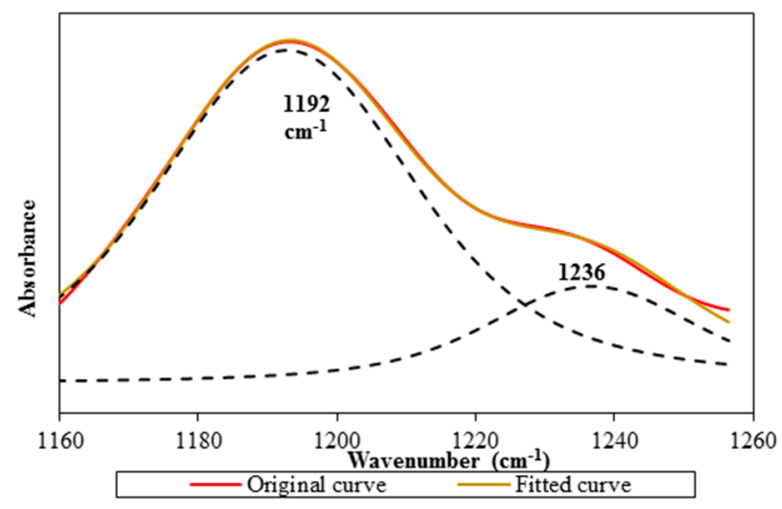

Figure 10. The original FTIR spectrum along with the fitted curve and deconvoluted peaks in the wavenumber region $1160-1260 \mathrm{~cm}^{-1}$.

It is noteworthy that two peaks are found at 1192 and $1236 \mathrm{~cm}^{-1}$ within the region. $\mathrm{CF}_{3}$ symmetric stretching mode is another vibrational mode to support the existence of the mobile ions. Figure 11 portrays an abrupt increase in peak intensity of $\mathrm{CF}_{3}$ symmetric stretching mode where the peak is increased by about $30.31 \%$ (from $4.49 \%$ to $34.80 \%$ ) in transmittance mode. 


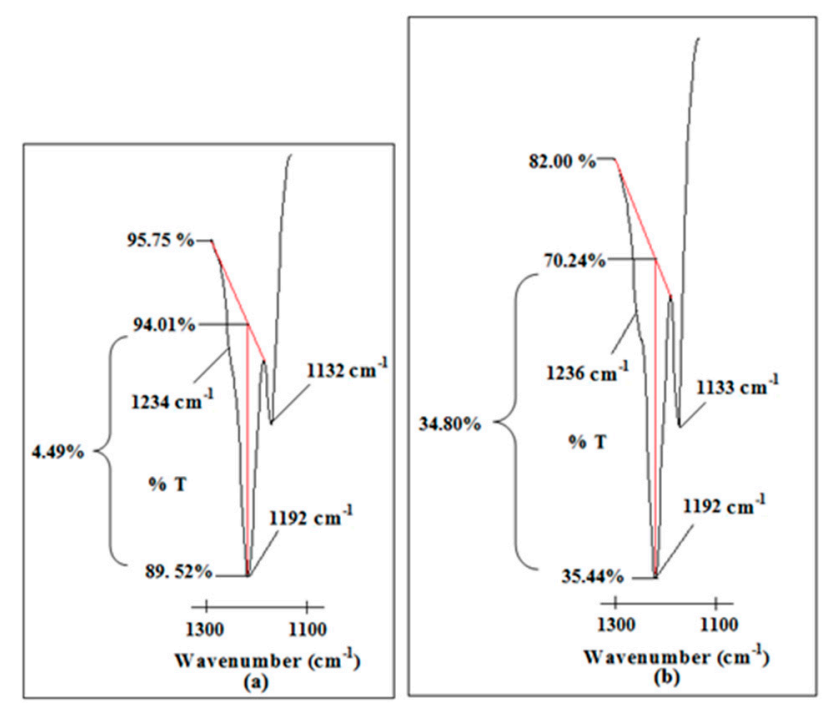

Figure 11. The changes in peak intensity of $\mathrm{CF}_{3}$ symmetric stretching mode of LiTFSI in (a) Ti 0 and (b) Ti 3.

The intense peak reveals that more TFSI free anions are produced in Ti 3 compared to Ti 0. As a result, these free ions could form complexation with the polymer matrix. Based on all of these findings, we can conclude that there is complexation between PAA and LiTFSI. We also prove that:

- The deprotonation of the carboxylic group in PAA has taken place for the conduction mechanism;

- $\quad$ Ti 3 has more mobile TFSI anions than Ti 0 which leads to higher ionic conductivity.

\subsection{Morphological Studies}

Spherulite is a highly complex ordered structure which consists of radially developed branching lamellar crystals which only normally can be observed in a material with high crystallinity. As observed in Figure 2a,b, no spherulitic structure can be observed in the SEM image of the filler-free and filler-added polymer electrolytes. This indicates the high amorphous nature of the developed polymer electrolyte samples $[47,48]$.

The filler-free polymer electrolytes showed a considerably smooth structure as seen in Figure 2a. This confirms the complete dissolution of the LiTFSI salt in the polymer matrix as there is no separate salt phases that can be seen in the SEM image. The morphology of the polymer electrolyte was observed to be changed after the addition of the $\mathrm{TiO}_{2}$ filler to the polymer electrolyte. As seen in Figure $2 b$, the filler-added polymer electrolyte was found to have a highly porous structure (dark region) and formed a lot of random distribution of pores compared to the filler-free polymer electrolyte. The changes in this morphology is an indication of the interaction between the $\mathrm{TiO}_{2}$ and the polymer electrolytes [49]. The addition of the $\mathrm{TiO}_{2}$ filler was also found to be able to promote the formation of pores on these PAA-based polymer electrolytes. Essentially, the ionic conductivity of a solid polymer electrolyte is attainable through continuous pathways which are interconnected by pores of the membranes. Thus, a highly porous structure is very favorable for a good ion-conducting polymer electrolyte. This is in agreement with the ionic conductivities studies where the filler-added polymer electrolyte is showing higher ionic conductivities in comparison with the filler-free polymer electrolyte [50].

\subsection{Linear Sweep Voltammetry (LSV)}

The operational voltage range of filler-free polymer electrolyte is $4.2 \mathrm{~V}$, ranging from -2 to $2.2 \mathrm{~V}$. On the other hand, the nanocomposite polymer electrolyte shows wider potential window of $4.6 \mathrm{~V}$ that is from -2.3 to $2.3 \mathrm{~V}$ in comparison to filler-free polymer electrolyte. We observe that the potential window of polymer electrolyte is expanded upon addition of nano-sized $\mathrm{TiO}_{2}$. Therefore, 
we can conclude that addition of nano-sized fillers can improve the electrochemical properties of the electrolyte.

\subsection{Cyclic Voltammetry (CV)}

The cyclic voltammetry of Ti 0-based EDLC shows a non-ideal rectangular shape with specific capacitance of $13.46 \mathrm{~F} \cdot \mathrm{g}^{-1}$ (or equivalent to $15 \mathrm{mF} \cdot \mathrm{cm}^{-2}$ ). Upon dispersion of nano-scaled fillers, the shape of the cyclic voltammetry approaches the ideal rectangular shape. The specific capacitance of EDLC containing the most conducting polymer electrolyte has doubled up to $28.56 \mathrm{~F} \cdot \mathrm{g}^{-1}$ (or equivalent to $29.54 \mathrm{mF} \cdot \mathrm{cm}^{-2}$ ). The energy storage of an EDLC arises from the charge accumulation between the electrode and electrolyte interface. The transported ions in the electrolyte will form an electrical double layer on the porous surface of the carbon-based electrode. The increase in capacitance of EDLC based on the nanocomposite polymer electrolyte is due to the increase in ionic conductivity of the polymer electrolyte. The rapid ion conduction mechanism in the electrolytes leads to the rapid ion adsorption at the boundary and, thereby, increases the energy storage in the EDLC.

Surprisingly, the capacitance of EDLC assembled in this research is higher than EDLC fabricating using ionic liquid-added polymer electrolyte membranes. EDLC comprising of ionic liquid-incorporated poly(ethylene oxide) polymer electrolyte membranes and multi-walled carbon nanotubes electrodes was prepared by Pandey and co-workers [51]. The fabricated EDLC showed the specific capacitance of $2.6-3 \mathrm{~F} \cdot \mathrm{g}^{-1}$ which is 10 times lower than our current work. The capacitance that we obtained from our published work is also lower than this current work. Ionic liquid-based poly(vinyl alcohol) (PVA) polymer electrolyte membranes are studied and investigated in our previous work. The EDLC fabricated using the same electrode depicted the specific capacitance of $21.89 \mathrm{~F} \cdot \mathrm{g}^{-1}$ which is slightly lower than this work [52]. Nanocomposite polymer electrolyte-based EDLCs are also prepared and investigated by our peers. Similar work composing of PVA-lithium perchlorate $\left(\mathrm{LiClO}_{4}\right)-\mathrm{TiO}_{2}$ polymer electrolyte is also prepared by Lim et al. [53]. The specific capacitance of $12.5 \mathrm{~F} \cdot \mathrm{g}^{-1}$ was obtained in the fabricated EDLC using nanocomposite polymer electrolyte. Biopolymer electrolyte membranes based on corn starch, $\mathrm{LiClO}_{4}$ and nano-sized silica are prepared by Teoh [54]. However, the specific capacitance of EDLC obtained from this work is lower than our current work, which is $8.71 \mathrm{~F} \cdot \mathrm{g}^{-1}$. Therefore, we conclude that the nanocomposite polymer electrolyte is a great candidate as an electrolyte in the EDLC.

\subsection{Galvanostatic Charge-Discharge Performance (GCD)}

EDLC is charged from 0 to $1 \mathrm{~V}$ and then discharged from 1 to $0 \mathrm{~V}$. EDLC produces the specific discharge capacitance of $26.23 \mathrm{~F} \cdot \mathrm{g}^{-1}$, energy density of $2.57 \mathrm{~W} \cdot \mathrm{h} \cdot \mathrm{kg}^{-1}$ and energy density of $467 \mathrm{~kW} \cdot \mathrm{kg}^{-1}$. The GCD curve shows the symmetrical shape during the charging and discharging processes with a Coulombic efficiency of $95 \%$.

Electrochemical stability of an EDLC is the main feature if it can be applied in the devices. The cell is charged and discharged for 3000 cycles. It is noteworthy that the specific capacitance of the cell increases with the cycle number up to $47.94 \mathrm{~F} \cdot \mathrm{g}^{-1}$ in the 300 th cycle. The specific capacitance of the cell remains unchanged until the 450th cycle. Beyond this cycle number, the specific capacitance of the EDLC is decreased. The specific capacitance of the cell is $23.66 \mathrm{~F} \cdot \mathrm{g}^{-1}$ at the 3000 th cycle. The reduction of capacitance is suggestive of the electrolyte depletion which affects the ion transportation within the polymer matrix. On the other hand, the Coulombic efficiency of the EDLC is maintained above $90 \%$ over 3000 cycles. This infers that the nanocomposite polymer electrolyte-based EDLC has stable electrochemical properties.

Energy density and power density of the EDLC demonstrate the same trend. An abrupt increase in energy density and a gradual increase in power density are observed from the 1st cycle to the 300th cycle. This is followed up by a moderate decrease in both densities above the 300th cycle of charging and discharging. The initial energy and power densities are $2.57 \mathrm{~W} \cdot \mathrm{h} \cdot \mathrm{kg}^{-1}$ and $467 \mathrm{~kW} \cdot \mathrm{kg}^{-1}$, respectively. The energy density is increased to $4.94 \mathrm{~W} \cdot \mathrm{h} \cdot \mathrm{kg}^{-1}$ at the 300 th cycle, whereas power 
density is increased to $481 \mathrm{~kW} \cdot \mathrm{kg}^{-1}$ at 350th cycle. The respective energy and power densities are further decreased to $0.59 \mathrm{~W} \cdot \mathrm{h} \cdot \mathrm{kg}^{-1}$ and $236 \mathrm{~kW} \cdot \mathrm{kg}^{-1}$ at the 3000th cycle. Nanocomposite polymer electrolyte membranes can be a good replacement for ionic liquid-based polymer electrolyte membranes. Based on these findings, EDLC comprising nanocomposite polymer electrolytes can be applied to be an energy storage device as a power system in our daily life.

\section{Conclusions}

PAA-based nanocomposite polymer electrolyte membranes are prepared and investigated in this work. Upon dispersion of nano-sized $\mathrm{TiO}_{2}$, the ionic conductivity of polymer electrolyte membranes is increased greatly. The complexation between PAA and LiTFSI is confirmed in FTIR analysis. SEM studies reveal that the filler-added polymer electrolytes have higher porosity. EDLC comprising nanocomposite polymer electrolytes and carbon electrodes is fabricated and studied through CV and GCD techniques. Addition of filler also increases the specific capacitance of EDLC. The fabricated EDLC shows the specific capacitance of 28.56 and $26.23 \mathrm{~F} \cdot \mathrm{g}^{-1}$ in CV and GCD curves, respectively. The maximum specific capacitance of $47.94 \mathrm{~F} \cdot \mathrm{g}^{-1}$ is achieved after charging and discharging for 300 cycles. EDLC illustrates superior Coulombic efficiency which remains above $90 \%$ over 3000 cycles. EDLC produces an energy density of $2.57 \mathrm{~W} \cdot \mathrm{h} \cdot \mathrm{kg}^{-1}$ and power density of $467 \mathrm{~kW} \cdot \mathrm{kg}^{-1}$. Nanocomposite polymer electrolyte is a superior electrolyte to be applied in EDLC application as it shows excellent electrochemical performance.

Acknowledgments: This work was supported by the High Impact Research Grant (H-21001-F000046) and Fundamental Research Grant Scheme (FP012-2015A) from Ministry of Education, Malaysia.

Author Contributions: S. Ramesh conducted and supervised the project including the supports for characterizations; Chiam-Wen Liew conceived and designed and performed the experiments; Chiam-Wen Liew, H.M. Ng and Arshid Numan analyzed the data; Chiam-Wen Liew and H.M. Ng wrote the paper.

Conflicts of Interest: The authors declare no conflict of interest.

\section{References}

1. Adebahr, J.; Byrne, N.; Forsyth, M.; MacFarlane, D.R.; Jacobsson, P. Enhancement of ion dynamics in PMMA-based gels with addition of $\mathrm{TiO}_{2}$ nano-particles. Electrochim. Acta 2003, 48, 2099-2103. [CrossRef]

2. Armand, M.B. Polymer electrolytes. Ann. Rev. Mater. Sci. 1986, 16, 245-261. [CrossRef]

3. Gray, F.M. Solid Polymer Electrolytes: Fundamentals of Technological Applications, 1st ed.; Wiley-VCH: New York, NY, USA, 1991; pp. 1-30.

4. Ramesh, S.; Liew, C.-W. Development and investigation on PMMA-PVC blend-based solid polymer electrolytes with LiTFSI as dopant salt. Polym. Bull. 2013, 70, 1277-1288. [CrossRef]

5. Baskaran, R.; Selvasekarapandian, S.; Kuwata, N.; Kawamura, J.; Hattori, T. Structure, thermal and transport properties of PVAc- $\mathrm{LiClO}_{4}$ solid polymer electrolytes. J. Phys. Chem. Solids 2007, 68, 407-412. [CrossRef]

6. Imrie, C.T.; Inkster, R.T.; Lu, Z.; Ingram, M. Discotic side group liquid crystal polymer electrolytes. Mol. Cryst. Liq. Cryst. 2004, 408, 33-43. [CrossRef]

7. Rajendran, S.; Sivakumar, M.; Subadevi, R. Investigations on the effect of the various plasticizers in PVA-PMMA solid polymer blend electrolytes. Mater. Lett. 2004, 58, 641-649. [CrossRef]

8. Krawiec, W.; Scanlon, L.G., Jr.; Fellner, J.P.; Vaia, R.A.; Vasudevan, S.; Giannelis, E.P. Polymer nanocomposites: A new strategy for synthesizing solid electrolytes for rechargeable lithium batteries. J. Power Sources 1995, 54, 310-315. [CrossRef]

9. Samir, M.A.S.A.; Alloin, F.; Sanchez, J.-Y.; Dufresne, A. Nanocomposite polymer electrolytes based on poly(oxyethylene) and cellulose whiskers. Polím. Ciênc. Tecnol. 2005, 15, 109-113. [CrossRef]

10. Jian-hua, T.; Peng-fei, G.; Zhi-yuan, Z.; Wen-hui, L.; Zhong-qiang, S. Preparation and performance evaluation of a Nafion- $\mathrm{TiO}_{2}$ composite membrane for PEMFCs. Int. J. Hydrogen Energy 2008, 33, 5686-5690. [CrossRef]

11. Kim, K.M.; Park, N.-G.; Ryu, K.S.; Chang, K.S. Characterization of poly(vinylidenefluorideco-hexafluoropropylene)-based polymer electrolytes filled with $\mathrm{TiO}_{2}$ nanoparticles. Polymer 2002, 43, 3951-3957. [CrossRef] 
12. Hammami, R.; Ahamed, Z.; Charradi, K.; Beji, Z.; Assaker, I.B.; Naceur, J.B.; Auvity, B.; Squadrito, G.; Chtourou, R. Elaboration and characterization of hybrid polymer electrolytes $\mathrm{Nafion}-\mathrm{TiO}_{2}$ for $\mathrm{PEMFCs}$. Int. J. Hydrogen Energy 2013, 38, 11583-11590. [CrossRef]

13. Saikia, D.; Chen-Yang, Y.W.; Chen, Y.T.; Li, Y.K.; Lin, S.I. ${ }^{7}$ Li NMR spectroscopy and ion conduction mechanism of composite gel polymer electrolyte: A comparative study with variation of salt and plasticizer with filler. Electrochim. Acta 2009, 54, 1218-1227. [CrossRef]

14. Yang, C.-C.; Chien, W.-C.; Li, Y.J. Direct methanol fuel cell based on poly(vinyl alcohol)/titanium oxide nanotubes/poly(styrene sulfonic acid) (PVA/nt-TiO $2 / \mathrm{PSSA})$ composite polymer membrane. J. Power Sources 2010, 195, 3407-3415. [CrossRef]

15. Mei, A.; Wang, X.-L.; Feng, Y.-C.; Zhao, S.-J.; Li, G.-J.; Geng, H.-X.; Lin, Y.-H.; Nan, C.-W. Enhanced ionic transport in lithium lanthanum titanium oxide solid state electrolyte by introducing silica. Solid State Ion. 2008, 179, 2255-2259. [CrossRef]

16. Boonsin, R.; Sudchanham, J.; Panusophon, N.; Sae-Heng, P.; Sae-Kung, C.; Pakawatpanurut, P. Dye-sensitized solar cell with poly(acrylic acid-co-acrylonitrile)-based gel polymer electrolyte. Mater. Chem. Phys. 2012, 132, 993-998. [CrossRef]

17. Tang, Z.; Liu, Q.; Tang, Q.; Wu, J.; Wang, J.; Chen, S.; Cheng, C.; Yu, H.; Lan, Z.; Lin, J.; et al. Preparation of PAA- $g$-CTAB/PANI polymer based gel-electrolyte and the application in quasi-solid-state dye-sensitized solar cells. Electrochim. Acta 2011, 58, 52-57. [CrossRef]

18. Shan, D.; Cheng, G.; Zhu, D.; Xue, H.; Cosnier, S.; Ding, S. Direct electrochemistry of hemoglobin in poly(acrylonitrile-co-acrylic acid) and its catalysis to $\mathrm{H}_{2} \mathrm{O}_{2}$. Sens. Actuat. B 2009, 137, 259-265. [CrossRef]

19. Shaikh, J.S.; Pawar, R.C.; Tarwal, N.L.; Patil, D.S.; Patil, P.S. Supercapacitor behavior of CuO-PAA hybrid films: Effect of PAA concentration. J. Alloy. Compd. 2011, 509, 7168-7174. [CrossRef]

20. Gu, X.; Wang, G. Interfacial morphology and friction properties of thin PEO and PEO/PAA blend films. Appl. Surf. Sci. 2011, 257, 1952-1959. [CrossRef]

21. Yin, Z.; Cui, R.; Liu, Y.; Jiang, L.; Zhu, J.-J. Ultrasensitive electrochemical immunoassay based on cadmium ion-functionalized PSA@PAA nanospheres. Biosens. Bioelectron. 2010, 25, 1319-1324. [CrossRef] [PubMed]

22. Dasenbrock, C.O.; Ridgway, T.H.; Seliskar, C.J.; Heineman, W.R. Evaluation of the electrochemical characteristics of a poly(vinyl alcohol)/poly(acrylic acid) polymer blend. Electrochim. Acta 1998, 43, 3497-3502. [CrossRef]

23. Huang, J.; Guo, Q.; Ohya, H.; Fang, J. The characteristics of crosslinked PAA composite membrane for separation of aqueous organic solutions by reverse osmosis. J. Membr. Sci. 1998, 144, 1-11. [CrossRef]

24. Shaikh, J.S.; Pawar, R.C.; Moholkar, A.V.; Kim, J.H.; Patil, P.S. CuO-PAA hybrid films: Chemical synthesis and supercapacitor behavior. Appl. Surf. Sci. 2011, 257, 4389-4397. [CrossRef]

25. Ohya, H.; Shibata, M.; Negish, Y.; Guo, Q.H.; Choi, H.S. The effect of molecular weight cut-off of PAN ultrafiltration support layer on separation of water-ethanol mixtures through pervaporation with PAA-PAN composite membrane. J. Membr. Sci. 1994, 90, 91-100. [CrossRef]

26. Moscoso-Londoño, O.; Gonzalez, J.S.; Muraca, D.; Hoppe, C.E.; Alvarez, V.A.; López-Quintela, A.; Socolovsky, L.M.; Pirota, K.R. Structural and magnetic behavior of ferrogels obtained by freezing thawing of polyvinyl alcohol/poly(acrylic acid) (PAA)-coated iron oxide nanoparticles. Eur. Polym. J. 2013, 49, 279-289. [CrossRef]

27. Elliott, J.E.; Macdonald, M.; Nie, J.; Bowman, C.N. Structure and swelling of poly(acrylic acid) hydrogels: Effect of $\mathrm{pH}$, ionic strength, and dilution on the crosslinked polymer structure. Polymer 2004, 45, 1503-1510. [CrossRef]

28. Kang, X. Nonaqueous liquid electrolytes for lithium-based rechargeable batteries. Chem. Rev. 2004, 104, 4303-4417.

29. Ramesh, S.; Lu, S.C. Effect of nanosized silica in poly(methyl methacrylate)-lithium bis(trifluoromethanesulfonyl)imide based polymer electrolytes. J. Power Sources 2008, 185, 1439-1443. [CrossRef]

30. Kim, K.M.; Ko, J.M.; Park, N.-G.; Ryu, K.S.; Chang, S.H. Characterization of poly(vinylidenefluorideco-hexafluoropropylene)-based polymer electrolyte filled with rutile $\mathrm{TiO}_{2}$ nanoparticles. Solid State Ion. 2003, 161, 121-131. [CrossRef] 
31. Arunmetha, S.; Manivasakan, P.; Karthik, A.; Babu, N.R.D.; Srither, S.R.; Rajendran, V. Effect of processing methods on physicochemical properties of titania nanoparticles produced from natural rutile sand. Adv. Powder Technol. 2013, 24, 972-979. [CrossRef]

32. Huang, S.-Y.; Ganesan, P.; Popov, B.N. Electrocatalytic activity and stability of niobium-doped titanium oxide supported platinum catalyst for polymer electrolyte membrane fuel cells. Appl. Catal. B 2010, 96, 224-231. [CrossRef]

33. Ekström, H.; Wickman, B.; Gustavsson, M.; Hanarp, P.; Eurenius, L.; Olsson, E.; Lindbergh, G. Nanometer-thick films of titanium oxide acting as electrolyte in the polymer electrolyte fuel cell. Electrochim. Acta 2007, 52, 4239-4245. [CrossRef]

34. Dittmann, R.; Wintermantel, E.; Graule, T. Sintering of nano-sized titania particles and the effect of chlorine impurities. J. Eur. Ceram. Soc. 2013, 33, 3257-3264. [CrossRef]

35. Mehta, M.; Raman, V.; Fox, R.O. On the role of gas-phase and surface chemistry in the production of titania nanoparticles in turbulent flames. Chem. Eng. Sci. 2013, 104, 1003-1018. [CrossRef]

36. Ning, X.; Wang, X.; Yu, X.; Zhao, J.; Wang, M.; Li, H.; Yang, Y. Outstanding supercapacitive properties of $\mathrm{Mn}$-doped $\mathrm{TiO}_{2}$ micro/nanostructure porous film prepared by anodization method. Sci. Rep. 2016, 6, 22634-22642. [CrossRef] [PubMed]

37. Raghavan, N.; Thangavel, S.; Venugopal, G. Enhanced photocatalytic degradation of methylene blue by reduced graphene-oxide/titanium dioxide/zinc oxide ternary nanocomposites. Mater. Sci. Semicond. Process. 2015, 30, 321-329. [CrossRef]

38. Bermudez, V.Z. Lithium-doped hybrid polymer electrolytes. In Polymer Electrolytes: Fundamentals and Applications; Sequeira, C., Santos, D., Eds.; Woodhead Publishing Limited: Cambridge, UK, 2010; pp. 176-218.

39. Ahmad, S.; Deepa, M.; Agnihotry, S.A. Effect of salts on the fumed silica-based composite polymer electrolytes. Sol. Energ. Mater. Sol. Cells 2008, 92, 184-189. [CrossRef]

40. Neira, A.; Tarraga, M.; Catalan, R. Degradation of polyacrylic acid by Fenton's reagent. J. Chil. Chem. Soc. 2007, 52, 1314-1317. [CrossRef]

41. Ali, A.M.M.; Yahya, M.Z.A.; Bahron, H.; Subban, R.H.Y.; Harun, M.K.; Atan, I. Impedance studies on plasticized PMMA-LiX $\left[X: \mathrm{CF}_{3} \mathrm{SO}_{3}{ }^{-}, \mathrm{N}\left(\mathrm{CF}_{3} \mathrm{SO}_{2}\right)_{2}{ }^{-}\right.$] polymer electrolytes. Mater. Lett. 2007, 61, 2026-2029. [CrossRef]

42. Jang, S.-R.; Choi, M.-J.; Vittal, R.; Kim, K.-J. Anchorage of N3 dye-linked polyacrylic acid to $\mathrm{TiO}_{2} /$ electrolyte interface for improvement in the performance of a dye-sensitized solar cell. Sol. Energ. Mater. Sol. Cells 2007, 91, 1209-1214. [CrossRef]

43. Bozkurt, A.; Meyer, W.H.; Wegner, G. PAA/imidazol-based proton conducting polymer electrolytes. J. Power Sources 2003, 123, 126-131. [CrossRef]

44. Tiwari, I.; Singh, K.P.; Singh, M.; Banks, C.E. Polyaniline/polyacrylic acid/multi-walled carbon nanotube modified electrodes for sensing ascorbic acid. Anal. Method 2012, 4, 118-124. [CrossRef]

45. Yuan, S.; Tang, Q.; He, B.; Yu, L. Conducting gel electrolytes with microporous structures for efficient quasi-solid-state dye-sensitized solar cells. J. Power Sources 2015, 273, 1148-1155. [CrossRef]

46. Capiglia, C.; Imanishi, N.; Takeda, Y.; Henderson, W.A.; Passerini, S. Polyethylene oxide $\mathrm{LiN}\left(\mathrm{SO}_{2} \mathrm{CF}_{2} \mathrm{CF}_{3}\right)_{2}$ polymer electrolytes IV. Raman characterization. J. Electrochem. Soc. 2003, 150, A525-A531. [CrossRef]

47. Pradeepa, P.; Edwinraj, S.; Ramesh Prabhu, M. Effects of ceramic filler in poly(vinyl chloride)/poly(ethyl methacrylate) based polymer blend electrolytes. Chin. Chem. Lett. 2015, 26, 1191-1196. [CrossRef]

48. Goldshtein, K.; Golodnitsky, D.; Peled, E.; Adler-Abramovich, L.; Gazit, E.; Khatun, S.; Stallworth, P.; Greenbaum, S. Effect of peptide nanotube filler on structural and ion-transport properties of solid polymer electrolytes. Solid State Ion. 2012, 220, 39-46.

49. Kumar, A.; Logapperumal, S.; Sharma, R.; Das, M.K.; Kar, K.K. Li-ion transport, structural and thermal studies on lithium triflate and barium titanate incorporated poly(vinylidene fluoride-co-hexafluoropropene) based polymer electrolyte. Solid State Ion. 2016, 289, 150-158.

50. Aravindan, V.; Vickraman, P. Lithium fluoroalkylphosphate based novel composite polymer electrolytes (NCPE) incorporated with nanosized $\mathrm{SiO}_{2}$ filler. Mater. Chem. Phys. 2009, 115, 251-257.

51. Pandey, G.P.; Kumar, Y.; Hashmi, S.A. Ionic liquid incorporated PEO based polymer electrolyte for electrical double layer capacitors: A comparative study with lithium and magnesium systems. Solid State Ion. 2011, 190, 93-98. 
52. Liew, C.-W.; Ramesh, S.; Arof, A.K. Characterization of ionic liquid added poly(vinyl alcohol)-based proton conducting polymer electrolytes and electrochemical studies on the supercapacitors. Int. J. Hydrogen Energy 2015, 40, 852-862.

53. Lim, C.-S.; Teoh, K.H.; Liew, C.-W.; Ramesh, S. Capacitive behavior studies on electrical double layer capacitor using poly(vinyl alcohol)-lithium perchlorate based polymer electrolyte incorporated with $\mathrm{TiO}_{2}$. Mater. Chem. Phys. 2014, 143, 661-667.

54. Teoh, K.H.; Lim, C.-S.; Liew, C.-W.; Ramesh, S. Electric double-layer capacitors with corn starch-based biopolymer electrolytes incorporating silica as filler. Ionics 2015, 21, 2061-2068.

(c)

(C) 2016 by the authors; licensee MDPI, Basel, Switzerland. This article is an open access article distributed under the terms and conditions of the Creative Commons Attribution (CC-BY) license (http://creativecommons.org/licenses/by/4.0/). 